\title{
Spatial Disparity of Knowledge Levels on Reproductive Health among Indonesia's Adolescents: Spatial Analysis of 2017 IDHS Data
}

\author{
Muhammad Rafif and Umi Listyaningsih \\ Department of Environmental Geography, Faculty of Geography, \\ Universitas Gadjah Mada, Yogyakarta
}

Corresponding Author: Muhammad Rafif (email: muhammadrafif@mail.ugm.ac.id)

\begin{abstract}
The high number and percentage of Indonesia's adolescent population cannot be separated from the problems related to adolescent reproductive health, especially the lack of knowledge about reproductive health among Indonesia's adolescents in. This study aims to analyze the spatial distribution of knowledge on adolescent reproductive health in Indonesia. This study is a quantitative study using secondary data of 2017 IDHS data. Adolescent reproductive health knowledge is measured in a composite index by taking into account the five indicators, including knowledge of signs of puberty, fertile period and risk of pregnancy, anemia, HIV/ AIDS, and other sexually transmitted infections. This study used a comparative spatial analysis. The results confirmed that there were differences in the spatial distribution of the adolescents' knowledge level related to reproductive health in each province based on the adolescents' characteristics, including sex, age, and education level.
\end{abstract}

Keywords: knowledge on reproductive health; adolescents; spatial distribution

\section{Introduction}

Adolescence is known as a period of transition from childhood to adulthood that is characterized by rapid and sudden physical changes influenced by hormonal factors. One of these changes is shown in the development of the functions of reproductive organs and the growth of secondary reproductive organs (Pratiwi and Basuki, 2011). The adolescent population in Indonesia has a quite high percentage. The total population of adolescents, especially those aged 15-24 years, according to the 2010 Population Census was 40.772.367 people or 17.16 percent of the total population of Indonesia. This number is expected to keep increasing until 2020, considering that the population aged 5-9 years had the largest percentage of Indonesia's total population in 2010, amounting to 9.78 percent with a total of more than 23.2 million people. It was followed by the 10-14 year-age group with a total of more than 22.6 million people or 9.54 percent of the total Indonesia's population. The population aged 5-14 years will then replace the youth population aged 15-24 years in 10 years later from 2010.

The high number of Indonesia's adolescent population makes the issue of reproductive and sexual health among adolescents important for national development. That is also important to avoid and overcome the long-term impacts 
that can arise from reproductive and sexual health issues on adolescents (Pakasi and Kartikawati, 2013). The Economic and Social Commission for Asia and the Pacific (ESCAP) has determined that adolescent health is one of the important issues that needs to be considered by Asia Pacific countries, including Indonesia, who has the high number of adolescent population (ESCAP, 2001).

There are several main problems related to Indonesia's adolescent reproductive health, including the lack of information on reproductive health, the shift in adolescent sexual behavior, poor health services, and unsupportive legislation. These problems generally occur due to the lack of knowledge on adolescent reproductive health (Irawan, 2016). Therefore, information about adolescent reproductive knowledge plays an important role in overcoming the shift in values and deviant behavior among adolescents.

The lack of knowledge on adolescents about reproductive health can lead to problems related to adolescent behavior and reproduction, such as the tendency of adolescents to have sex before marriage, teenage pregnancy which then leads to widespread abortion practices due to unwanted pregnancies, high mortality of young mothers, and an increase in sexually transmitted disease cases, especially HIV/ AIDS (Pratiwi and Basuki, 2011). The 2017 IDHS data shows that 1.5 percent of unmarried women aged 15-24 years in Indonesia had premarital sexual intercourse and 7.6 percent in male adolescents. The highest number of premarital sex behavior among Indonesia's adolescents, especially male adolescents aged 20-24 years and not married yet, reached 14 percent. This number is estimated to be higher since the matters related to sexual activity is still considered taboo in Indonesia. Besides, based on the 2012 IDHS data, there are 6.9 out of 1.000 female adolescents aged 15-19 years who are pregnant and giving birth. Meanwhile, the Population Data Sheet issued by the Economic and Social Commission for Asia and the Pacific (ESCAP) in 2018 shows that the birth rate for women aged 15-19 years in Indonesia reaches 47.4 out of every 1.000 women aged $15-19$ years.

Wawan and Dewi (2011) stated that the knowledge level is influenced by internal and external factors. Internal factors are those that are inherent in each individual. It includes education, occupation, and age. The external factors affecting the knowledge of each person are environment and socioculture. Mingzhu Chen, et al. (2020) mentioned that education is one of the variables affecting knowledge on reproductive health. The lack of education results in the lack of knowledge on reproductive health. Meanwhile, the research results conducted by Dongxian Zhang, et al. (2010) on the multilinear regression showed that 11 out of 16 factors, including age, class, major, age of menarche, family residence, single child, and maternal occupation, are significantly related to knowledge.

Each region in Indonesia has different social, economic, and cultural characteristics. A research conducted by Oktarina et al. (2009), which aims to analyze the relationship of respondent characteristics, regional conditions with knowledge, and attitudes towards HIVIAIDS in Indonesian society, showed that there is a significant relationship between regional conditions and knowledge level. Ernawati's research (2018) also showed a tendency that adolescents who live in rural areas are less likely to obtain the source of information about reproductive health from their parents. This might happen since parents in rural areas still think that talking about reproduction with adolescents is taboo. A research conducted by Purwanto et al. (2010) also stated that there are differences in the knowledge level on reproductive health between rural and urban areas. This condition may be influenced by differences in the number 
of sources of information, socioeconomic status, and parental education. Therefore, differences in regional characteristics, both socially, economically and culturally, may provide variations in the level of adolescents' knowledge on reproductive health.

The differences in knowledge on reproductive health among adolescents by region may be related to the theory of spatial behavior. This theory or commonly known as human behavior in the context of space by Golledge and Stimson (1997) is defined as a manifestation of the physical settings of space as a result of human action, including human behavior towards space. The complexity of spatial behavior is related to the intersection between humans and their environment. This interaction involves variables of the natural and the artificial environment in which there are cultural, social, and political technology factors. Golledge and Stimson (1997) explain that the structure of the environment affects the learning process. Humans interact with their environment which is then responded to as knowledge. The learning process is influenced by and influences perceptions, which in the end, the understanding or knowledge gained by humans can change the structure of the environment. Vice versa, this environmental structure will be responded back and forth. This theory is explained in Figure 1.

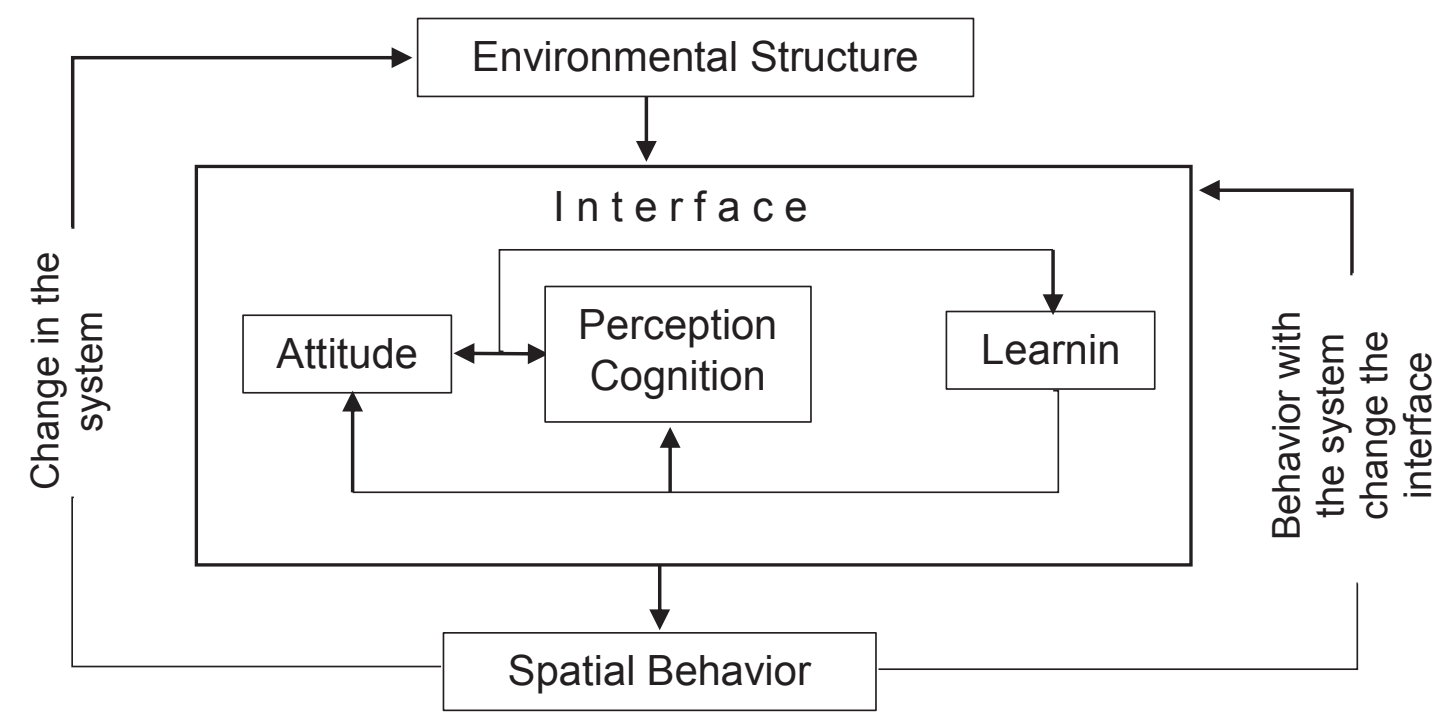

Source: Golledge and Stimson, 1997

Figure 1. Human Behavior and Environmental Interface

Environment in a geographic context is defined as all landscapes including local geographic conditions, both physical and human, and the accessibility of the area concerned (Hastuti and Suhardjo, 2006). If it is associated with environmental factors as external factors that affect the knowledge level, then the differences in the physical, social or human environment conditions and accessibility affect the knowledge level, thus causing differences in the knowledge level in each of these environmental conditions. The difference in the characteristics of the level of adolescents' knowledge on reproductive health in each region, which is at the provincial level, can be useful in finding out 
what factors cause the knowledge level to be high in one province, while low in other provinces. Through the spatial distribution, it is also possible to see what steps need to be improved and what kind of programs are needed and adjusted to the conditions and characteristics of the area.

\section{Methodology}

This study is a quantitative research conducted through composite tabulation to measure the knowledge level on reproductive health among adolescents in every province of Indonesia. The composite index obtained in this study was then carried out using spatial analysis by means of mapping. This was performed to see an overview of the spatial distribution of the level of reproductive health knowledge in Indonesia. The data used in this study is secondary data from the 2017 Indonesian Demographic and Health Survey (IDHS) consisting of data on Adolescent Reproductive Health (ARH) components.

The variable of the knowledge level on reproductive health in this study is based on the concept of reproductive health according to WHO. Which explains that reproductive health is not only free from diseases or defects in the reproductive organs, but also its functions and processes with regard to all matters concerning the reproductive system. The indicators of reproductive health knowledge are adjusted to the 2017 IDHS questionnaire, so that the knowledge on the reproductive system, function, and processes is measured through indicators of knowledge on signs of puberty and knowledge on fertility and pregnancy risks. The knowledge on diseases related to the reproductive system is measured through indicators of knowledge on anemia, HIVIAIDS, and other sexually transmitted infections.

For this study, each indicator was measured based on the percentage of adolescents who knew about the topic of the indicator correctly. Adolescent's reproductive health knowledge in this study will be differentiated based on adolescent characteristics, including sex, age, and education level. This is because these three characteristics are several factors affecting the differences in the knowledge level possessed by individuals (Wawan and Dewi, 2011; Oktarina et al, 2009). Sex is divided into male adolescents and female adolescents; ages are divided into adolescents aged 1519 years and 20-24 years; and education levels can be divided into two, i.e., low educated adolescents (graduated from junior high school and below) and high educated adolescents (at least graduated from high school).

The composite tabulation in this study is based on the research of Sutono and Listyaningsih (2014). The variables used in the calculation of the composite index consisted of five indicators (knowledge on signs of puberty, fertility and risk of pregnancy, anemia, HIVIAIDS, and other STIs). Furthermore, the following steps were performed to calculate the composite index:

1. Data from each sub-indicator in the form of a percentage was classified into three categories, i.e., low, medium, and high. The criteria for each of these categories consist of the following description:

Low: data with a percentage between 0 $-33.32 \%$

Medium: data with a percentage between $33.33-66.66 \%$

High: data with a percentage of $66.67 \%$ $-100 \%$

2. Based on these categories, composite tabulation was then performed by scoring each sub-indicator based on the category of sub-indicator. The score for the "low" category was 10, "medium" was 20 , and "high" was 30.

3. After scoring each sub-indicator class, the average sub-indicator score was calculated by accumulating the score of all sub-indicators, then dividing it by the number of all the sub-indicators on 
each constituent indicator. Therefore, the composite index of the knowledge level of adolescents on reproductive health could be calculated by comparing the average sub-indicator score with the highest sub-indicator conversion score. The composite index formula is presented as follows.

$$
T=\frac{\text { Average score of all sub }- \text { indicators }}{\text { Highest score for conversion of sub }- \text { indicators }}
$$

Information:

$T=$ Composite Index of Knowledge Level on Reproductive Health

The Composite Index was obtained using a comparative spatial analysis. This analysis was performed by grouping the composite scores for the knowledge level on reproductive health based on the characteristics of adolescents which were classified into 2, i.e., "high" for the provincial composite score of more than 0.66 on a scale of $0-1$ and "low" for the provincial composite value between $0.33-0.66$. The data classification for each province is presented in a map to see the spatial distribution, so the differences in each province can be seen according the adolescents' knowledge level on reproductive health and the adolescents characteristics.

\section{Results and Discussion}

Thecompositeindexofthe knowledgelevel on reproductive health presents an illustration of the knowledge of all components, including knowledge on signs of puberty, fertility period, and the risk of pregnancy, anemia, HIVIAIDS and other sexually transmitted infections. The composite index in this study ranged from 0.33 to 1 , so it had a middle value of 0.67 . The middle value indicates that there were only half of adolescents on average who understood well about reproductive health, thus an index value of less than 0.67 indicates that more than half of adolescents did not know reproductive health well. The value of 0.67 is included in the high category, so the high category indicates a maximum of half of adolescents (50 percent) who did not know about reproductive health well, and if it was more than half, it is the included in the "low" category.

\section{Sex}

Table 1 shows the distribution of the composite index value for the adolescents' knowledge level on reproductive health by province in Indonesia's male and female adolescents, i.e., 0.67 and 0.64 respectively is. At the national level, the index value for male adolescents is higher than female adolescents. However, according to the province of male adolescents, less than half of the provinces in Indonesia (14 provinces) have an index value of more than 0.66 , so more than half provinces have a low knowledge level on reproductive health. Meanwhile, among female adolescents by province, more than half of them (i.e., 18 out of 34 provinces) have an index value of more than 0.66 , so there are 16 provinces in Indonesia that have a low knowledge level on reproductive health.

The highest index value was obtained by the Province of Bali for both male and female adolescents, i.e., 0.85 and 0.82 respectively. This is in line with the results of a research conducted by Iswarati (2011) which states that the highest index value was found in Bali Province. Meanwhile, the provinces with the lowest index value were West Kalimantan and North Sumatra, with an index value of 0.56 for male adolescents and index value of 0.51 for female adolescents in Papua. 
Overall, the index value for the knowledge level on reproductive health, which was distinguished by sex, found a tendency for differences. It shows that male adolescents tend to have a higher knowledge level than the female adolescents. This is in line with the results of a study conducted by Wahyuni (2012) which states that female adolescents tend to have lower knowledge than the male adolescents since differences in knowledge may be influenced by personality factors and their social environment. Male adolescents are more open with information about reproduction, compared to the female adolescents who tend to be introverted. The results of this study also support the theory of a study conducted by Oktarina et al. (2009) that the knowledge level has a significant relationship with gender differences.
The spatial distribution through the map shown in Figure 1a indicating the relatively low knowledge level on reproductive health among Indonesia's male adolescents is found in the provinces located on the mainland of Sumatra Island and the Eastern Indonesian Archipelago, from East Nusa Tenggara, Maluku to Papua. Meanwhile, the relatively high knowledge level on reproductive health among male adolescents is focused on provinces located on the island of Java, except West Java and several other provinces, including Riau, Bangka Belitung, South Kalimantan, East Kalimantan, Bali, West Nusa Tenggara, Central Sulawesi, and North Sulawesi.

\section{Table 1. The Composite Index of Adolescents' Knowledge on Reproductive Health by Sex}

\begin{tabular}{|l|c|c|}
\hline \multirow{2}{*}{\multicolumn{1}{|c|}{ Province }} & \multicolumn{2}{c|}{$\begin{array}{c}\text { The Composite Index } \\
\text { of Reproductive } \\
\text { Health Knowledge }\end{array}$} \\
\cline { 2 - 3 } & Male & Female \\
\hline Aceh & 0.62 & 0.64 \\
\hline North Sumatra & 0.56 & 0.62 \\
\hline West Sumatra & 0.62 & 0.67 \\
\hline Riau & 0.59 & 0.67 \\
\hline Jambi & 0.59 & 0.62 \\
\hline South Sumatra & 0.59 & 0.64 \\
\hline Bengkulu & 0.64 & 0.64 \\
\hline Lampung & 0.64 & 0.67 \\
\hline Bangka Belitung & 0.67 & 0.69 \\
\hline Riau Islands & 0.77 & 0.74 \\
\hline Jakarta & 0.69 & 0.72 \\
\hline West Java & 0.62 & 0.67 \\
\hline Central Java & 0.72 & 0.74 \\
\hline Yogyakarta & 0.72 & 0.72 \\
\hline East Java & 0.72 & 0.74 \\
\hline Banten & 0.67 & 0.69 \\
\hline Bali & 0.85 & 0.82 \\
\hline
\end{tabular}

Source: 2017 IDHS Data (Processed)

\begin{tabular}{|l|c|c|}
\hline \multirow{2}{*}{\multicolumn{1}{|c|}{ Province }} & \multicolumn{2}{c|}{$\begin{array}{c}\text { The Composite Index } \\
\text { of Reproductive } \\
\text { Health Knowledge }\end{array}$} \\
\cline { 2 - 3 } & Male & Female \\
\hline West Nusa Tenggara & 0.67 & 0.69 \\
\hline East Nusa Tenggara & 0.59 & 0.64 \\
\hline West Kalimantan & 0.56 & 0.64 \\
\hline Central Kalimantan & 0.62 & 0.72 \\
\hline South Kalimantan & 0.69 & 0.69 \\
\hline East Kalimantan & 0.69 & 0.67 \\
\hline North Kalimantan & 0.62 & 0.62 \\
\hline North Sulawesi & 0.67 & 0.64 \\
\hline Central Sulawesi & 0.67 & 0.67 \\
\hline South Sulawesi & 0.62 & 0.64 \\
\hline Southeast Sulawesi & 0.62 & 0.64 \\
\hline Gorontalo & 0.62 & 0.64 \\
\hline West Sulawesi & 0.59 & 0.64 \\
\hline Maluku & 0.62 & 0.64 \\
\hline North Maluku & 0.59 & 0.64 \\
\hline West Papua & 0.64 & 0.69 \\
\hline Papua & 0.64 & 0.51 \\
\hline INDONESIA & 0.67 & 0.64 \\
\hline
\end{tabular}




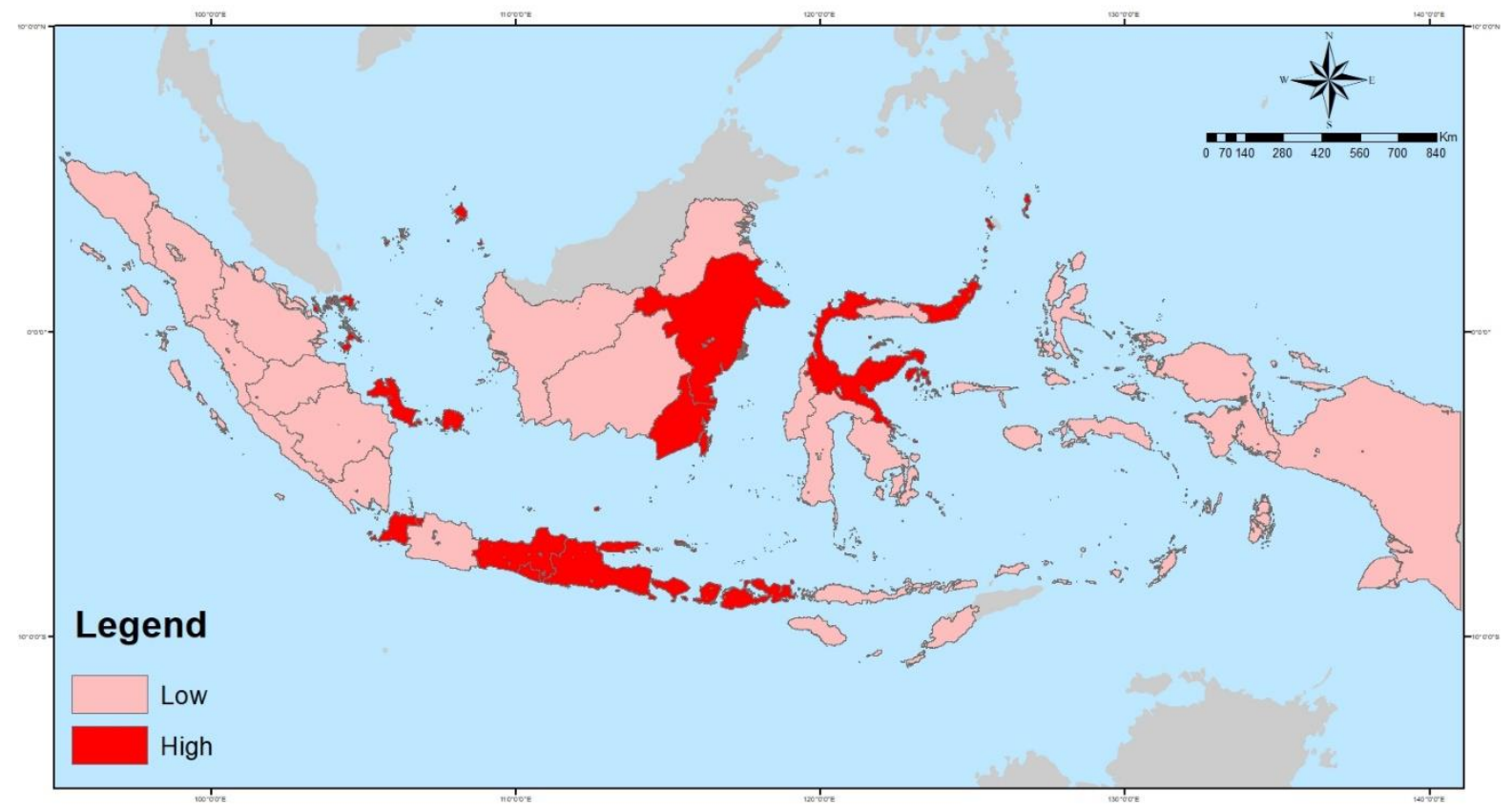

Source: 2017 IDHS Data (Processed)

Figure 1a. Spatial Distribution of the Knowledge Level on Reproductive Health among Male Adolescents by Province, 2017

Figure $1 \mathrm{~b}$ shows that there are provinces located in the Sumatra with a high knowledge levelclassificationamongfemaleadolescents, including West Sumatra, Riau, Lampung, Riau, and Bangka Belitung. It indicates that the level of knowledge on reproductive health among female adolescents is better than that of male adolescents in provinces located in the Sumatra Islands. The high knowledge level among female adolescents in that region is partly influenced by the fact that the indicators of knowledge on anemia tend to be higher among adolescent female than that of male adolescents in these provinces. This condition shows that knowledge on anemia among Indonesia's adolescents is generally more widely known by female adolescents compared to male adolescents. This can certainly be considered positive since there is a theory stating that young women are at the highest risk of anemia, especially during adolescence compared to male adolescents (Sari et al., 2019). The more female adolescents who know about anemia knowledge, it is hoped that it can reduce more the number of anemia sufferers among Indonesia's adolescents according to the theory that adolescents who have a knowledge level are 2.3 times less at risk of developing anemia compared to adolescents who do not (Martini, 2015).

The same thing can also be found in the provinces located in Kalimantan, in which not only East Kalimantan and South Kalimantan provinces have a high category of knowledge level among male adolescents, but Central Kalimantan also has a high category of knowledge level among young women. Besides, female adolescents in provinces located in Eastern Indonesia, i.e., West Papua Province, are also high. The high knowledge level on the reproductive health among adolescent women in West Papua can be influenced by the high level of education among women in that province. Based on data from the Indonesian Women's Profile in 2019, the percentage of women aged 15 years and older in West Papua 
Province is 42.58 percent, consisting of high school and university graduates. This number is even higher when compared to provinces located on the island of Java, such as West Java, Central Java, and East Java, where only 20-30 percent of women aged 15 years and over have graduated from high school and tertiary education. This condition is supported by many studies which show that the higher a person's level of education, the higher knowledge level he has. These studies include a research conducted by Panonsih et al. (2020), Oktarina et al. (2009), and Asiah (2009).

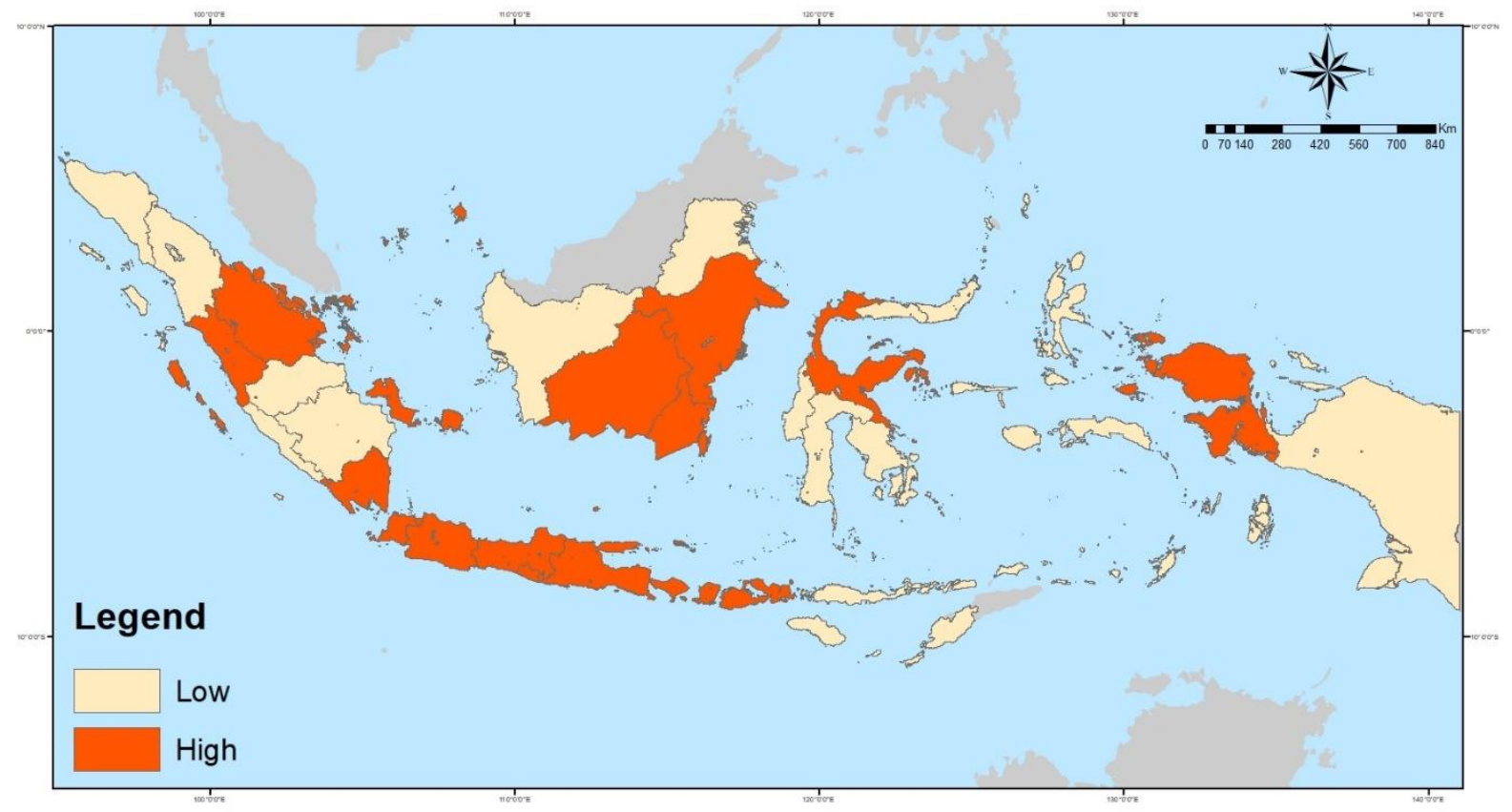

Source: 2017 IDHS Data (Processed)

Figure 1b. Spatial Distribution of the Knowledge Level on Reproductive Health among Adolescent Female by Province, 2017

\section{Age}

Composite index according to provinces in Indonesia, which is distinguished by adolescent age group, consist of adolescents aged $15-19$ years and $20-24$ years. Based on Table 2, the composite index value in national level shows 0.62 among adolescents aged 15 19 years and 0.69 among adolescents aged 20-24 years. It shows that the knowledge level was still low among adolescents aged 15-19 years. According to the province, there were only eight provinces with an index value of more than 0.66 or classified as "high" among adolescents, including Bali, Riau,
East Java, Central Java, East Kalimantan, Central Kalimantan, Yogyakarta, and Jakarta. Meanwhile, adolescents aged 20-24 years are just the opposite because there were only nine provinces with an index value of less than 0.66 or classified as "low", including Papua, North Maluku, West Kalimantan, West Sulawesi, North Kalimantan, Riau, Aceh, East Nusa Tenggara, and North Sumatra.

The group of adolescents aged 1519 years had a range of values from the highest to the lowest of 0.26 with the highest index value of 0.77 found in Bali and the lowest index value of 0.51 in North Maluku. Meanwhile, in the group of adolescents 
aged 20-24 year, the range of values from the highest to the lowest was 0.28 with the highest score of 0.87 in Bali and the lowest value of 0.59 in East Nusa Tenggara and
North Sumatra. This condition is the same as in the composite index value by sex since Bali Province still had the highest index in Indonesia.

\section{Table 2. The Composite Index of Adolescents' Knowledge on Reproductive Health by Age}

\begin{tabular}{|l|c|c|}
\hline \multirow{2}{*}{\multicolumn{1}{|c|}{ Province }} & \multicolumn{2}{c|}{$\begin{array}{c}\text { The Composite Index } \\
\text { of Reproductive } \\
\text { Health Knowledge }\end{array}$} \\
\cline { 2 - 3 } & $\mathbf{1 5 - 1 9}$ & $\mathbf{2 0 - 2 4}$ \\
\hline Aceh & 0.62 & 0.62 \\
\hline North Sumatra & 0.59 & 0.59 \\
\hline West Sumatra & 0.64 & 0.69 \\
\hline Riau & 0.59 & 0.62 \\
\hline Jambi & 0.59 & 0.67 \\
\hline South Sumatra & 0.54 & 0.67 \\
\hline Bengkulu & 0.62 & 0.69 \\
\hline Lampung & 0.62 & 0.67 \\
\hline Bangka Belitung & 0.62 & 0.69 \\
\hline Riau Islands & 0.74 & 0.82 \\
\hline Jakarta & 0.67 & 0.74 \\
\hline West Java & 0.62 & 0.67 \\
\hline Central Java & 0.69 & 0.74 \\
\hline Yogyakarta & 0.67 & 0.74 \\
\hline East Java & 0.69 & 0.74 \\
\hline Banten & 0.64 & 0.72 \\
\hline Bali & 0.77 & 0.87 \\
\hline
\end{tabular}

\begin{tabular}{|l|c|c|}
\hline \multirow{2}{*}{\multicolumn{1}{|c|}{ Province }} & \multicolumn{2}{|c|}{$\begin{array}{c}\text { The Composite Index } \\
\text { of Reproductive } \\
\text { Health Knowledge }\end{array}$} \\
\cline { 2 - 3 } & $\mathbf{1 5 - 1 9}$ & $\mathbf{2 0 - 2 4}$ \\
\hline West Nusa Tenggara & 0.64 & 0.74 \\
\hline East Nusa Tenggara & 0.56 & 0.59 \\
\hline West Kalimantan & 0.56 & 0.64 \\
\hline Central Kalimantan & 0.67 & 0.72 \\
\hline South Kalimantan & 0.64 & 0.72 \\
\hline East Kalimantan & 0.67 & 0.74 \\
\hline North Kalimantan & 0.56 & 0.62 \\
\hline North Sulawesi & 0.62 & 0.69 \\
\hline Cenrtal Sulawesi & 0.62 & 0.72 \\
\hline South Sulawesi & 0.59 & 0.67 \\
\hline Southeast Sulawesi & 0.59 & 0.67 \\
\hline Gorontalo & 0.54 & 0.69 \\
\hline West Sulawesi & 0.56 & 0.62 \\
\hline Maluku & 0.56 & 0.67 \\
\hline North Maluku & 0.51 & 0.64 \\
\hline West Papua & 0.56 & 0.67 \\
\hline Papua & 0.54 & 0.64 \\
\hline INDONESIA & 0.62 & 0.69 \\
\hline
\end{tabular}

Source: 2017 IDHS Data (Processed)

The difference in index values in the group of adolescents aged 15-19 years and 20-24 years shows a tendency where the index value of adolescents' knowledge on reproductive health at the age of 15-19 years was lower than those aged 20-24. It means that adolescents aged 20-24 years knew more about reproductive health than those aged 15-19 years. According to Handhika et al. (2017) in their research, the higher the age of a person, the higher maturity level and strength in thinking and working will increase. In addition, this is also supported by a research conducted by Suwaryo and Yuwono (2017) that, at the age of 20-35 years, a person will tend to be more active in society and their social life by making more preparations for adjustment to old age, so they will get more knowledge as well.

Figure $2 \mathrm{a}$ and Figure $2 \mathrm{~b}$ show a map of the spatial distribution of knowledge of reproductive health among adolescents aged 15-19 and 20-24 years, by provinces in Indonesia. The map shows the spatial distribution of knowledge levels among adolescents aged $15-19$ years who tends to be 
low in many Indonesian provinces. Provinces that fall into the high category in this age group tend to cover several provinces in the east of Java Island including Bali, which are Central Java, Yogyakarta, East Java, and Bali. In addition, it is found in several provinces on the island of Kalimantan, including Central Kalimantan and East Kalimantan. The Riau Islands Province is also a province with a high knowledge level among adolescents aged 15-19 years (Figure 2a).

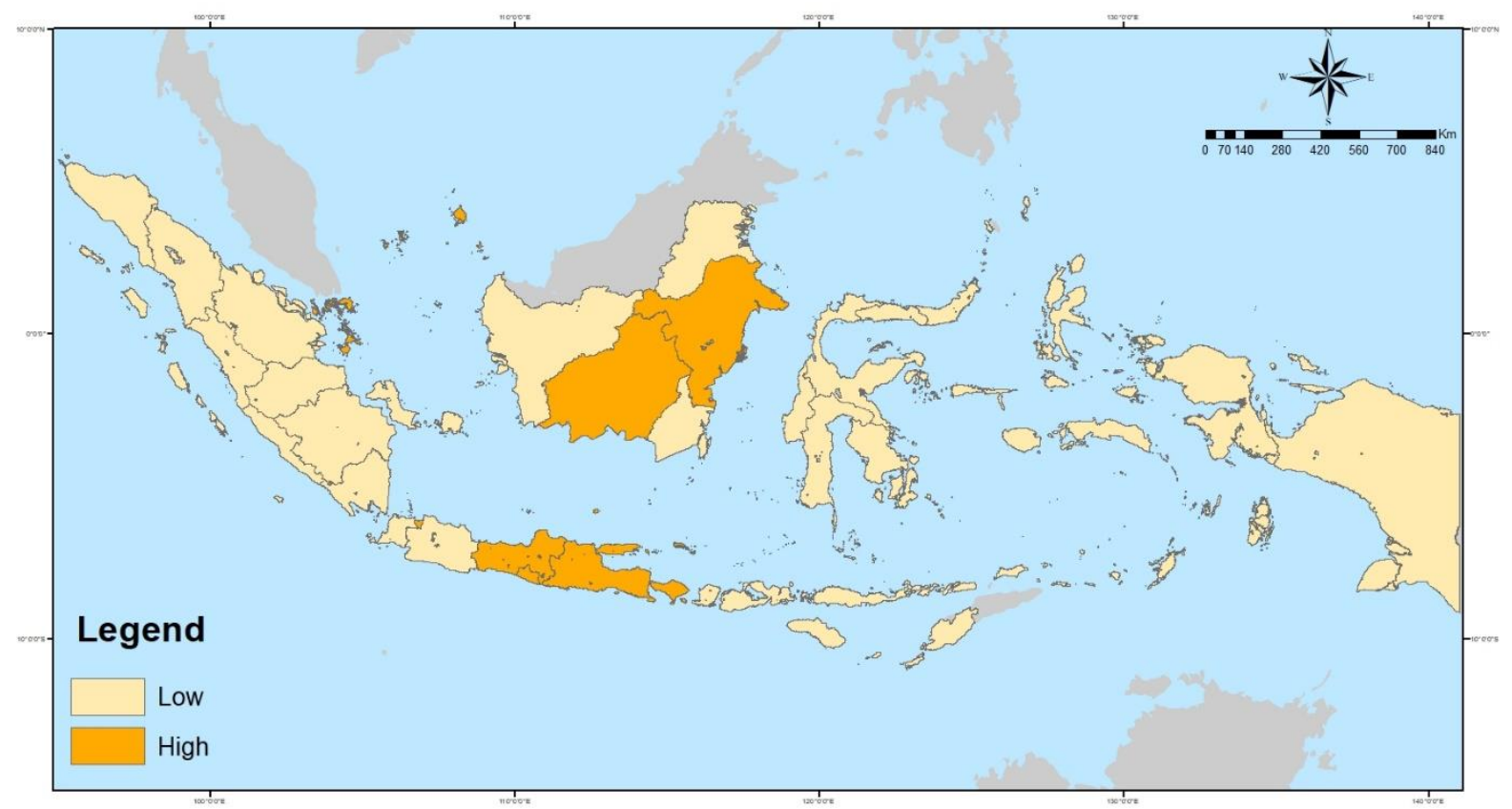

Source: 2017 IDHS Data (Processed)

Figure 2a. Spatial Distribution of the Level of Reproductive Health Knowledge on Adolescent 15-19 years old, by Province, 2017

The spatial distribution of the knowledge level on reproductive health among adolescents aged 20-24 years shows a significant difference in adolescents aged 15-19 years. The relatively high spatial distribution of knowledge level among adolescents aged 20-24 years tends to cover a wider area and includes more provinces. The provinces with the low category are located in the outer regions of the islands in Indonesia, such as Aceh, West Kalimantan, North Kalimantan, North Maluku, and Papua (Figure 2b). This condition indicates that the relatively high knowledge level on reproductive health among adolescents aged
20-24 years focused on affordable provinces that are not too far from the development center in Java.

However, based on the spatial distribution of knowledge level on reproductive health among adolescents aged 15-19 years, there were several provinces classified as high. Also, among adolescents aged 20-24 years, there were several provinces with relatively low knowledge level. This condition can be assumed since it is influenced by one of the external factors. The CHDI (Community Health Development Index), which takes into account the aspects of reproductive health, shows that provinces with a high 
knowledge level among adolescents aged 15-19 years and 20-24 years have Public Health Development Index (IPKM) scores that tend to be above the Indonesian IPKM value, which is equal to 0.6087 . The provinces, including Bali, Yogyakarta, Riau, Jakarta, Central Java, and East Java are 6 (six) provinces with the highest IPKM scores in Indonesia in 2018 (Ministry of Health of the Republic of Indonesia, 2019).

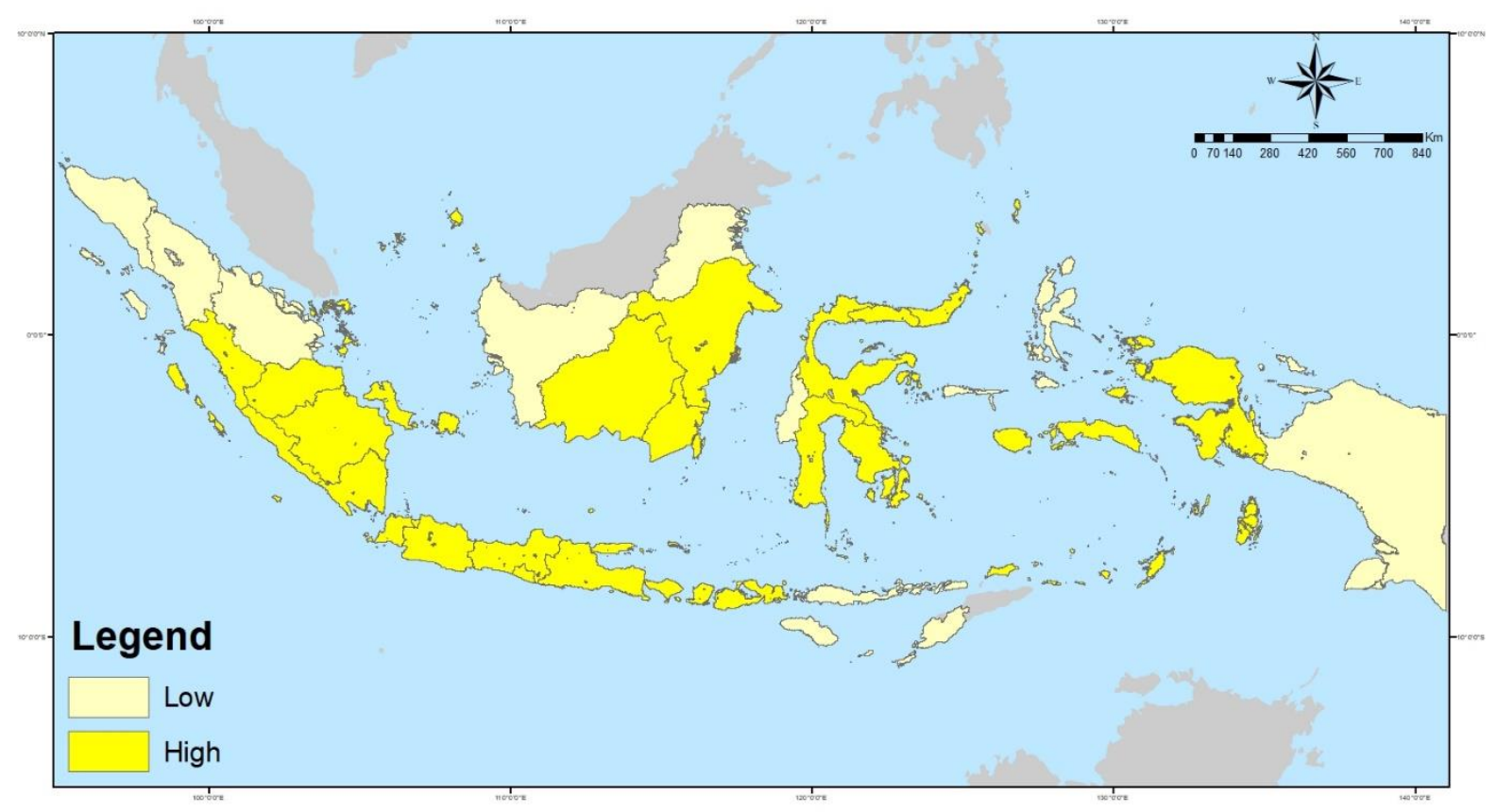

Source: 2017 IDHS Data (Processed)

Figure 2b. Spatial Distribution of the Knowledge Level on Reproductive Health among Adolescents Aged 20-24 years, by Province, 2017

\section{Education Level}

The distribution of composite index scores for the knowledge level on reproductive health among adolescents is distinguished by the adolescents' education level, i.e., low education level and high education level. Table 3 shows that the index value of the knowledge level among Indonesia's adolescents by education level reached 0.51 for adolescents with low education level and 0.67 for adolescents with high of education level. The range of values for adolescents with a low education level was 0.26 , with the highest index value obtained by Bali at
0.67 and the lowest value of 0.41 obtained by Papua, North Maluku, Maluku, West Sulawesi, and South Sulawesi. Meanwhile, the range of values in the adolescent group with a higher education level was also 0.26 , where Bali still received the highest index value of 0.85 and North Maluku, West Sulawesi and North Sumatra got the lowest index value of 0.59 .

Adolescents with low education level knew less about reproductive health. It indicates that there was only one province with an index value of more than 0.66 , so the other 33 provinces were still classified as the provinces with low education level. 
Meanwhile, there were 15 provinces with an index value of less than 0.66 (classified as low) among adolescents with a high education level. This condition is in line with many theories and research results which state that the higher a person's education level is, the more insightful and knowledgeable he will be.

\section{Table 3. The Composite Index of Knowledge on Reproductive Health by Education Level}

\begin{tabular}{|l|c|c|}
\hline \multirow{2}{*}{\multicolumn{1}{|c|}{ Province }} & \multicolumn{2}{c|}{$\begin{array}{c}\text { The Composite Index } \\
\text { of Reproductive Health } \\
\text { Knowledge }\end{array}$} \\
\cline { 2 - 3 } & Low Ed. & High Ed. \\
\hline Aceh & 0.49 & 0.62 \\
\hline North Sumatra & 0.46 & 0.59 \\
\hline West Sumatra & 0.51 & 0.64 \\
\hline Riau & 0.49 & 0.64 \\
\hline Jambi & 0.54 & 0.62 \\
\hline South Sumatra & 0.49 & 0.62 \\
\hline Bengkulu & 0.49 & 0.62 \\
\hline Lampung & 0.51 & 0.67 \\
\hline Bangka Belitung & 0.56 & 0.69 \\
\hline Riau Islands & 0.64 & 0.79 \\
\hline Jakarta & 0.59 & 0.74 \\
\hline West Java & 0.56 & 0.67 \\
\hline Central Java & 0.59 & 0.74 \\
\hline Yogyakarta & 0.56 & 0.69 \\
\hline East Java & 0.56 & 0.77 \\
\hline Banten & 0.56 & 0.69 \\
\hline Bali & 0.67 & 0.85 \\
\hline
\end{tabular}

Source: 2017 IDHS Data (Processed)

These studies include a research conducted by Panonsih et al. (2020) which states that there is a positive relationship between education level and knowledge level. Moreover, a research conducted by Oktarina et al. (2009) states that there is a significant relationship between education level and knowledge level. Also, Asiah (2009) also reveals that there is a relationship between education level and knowledge on reproductive health with a strong and linear correlation. It means that the higher of one's education level, the higher the knowledge on reproductive health he will obtain.

\begin{tabular}{|l|c|c|}
\hline \multirow{2}{*}{\multicolumn{1}{|c|}{ Province }} & \multicolumn{2}{c|}{$\begin{array}{c}\text { The Composite Index } \\
\text { of Reproductive Health } \\
\text { Knowledge }\end{array}$} \\
\cline { 2 - 3 } & Low Ed. & High Ed. \\
\hline West Nusa Tenggara & 0.56 & 0.64 \\
\hline East Nusa Tenggara & 0.46 & 0.62 \\
\hline West Kalimantan & 0.46 & 0.64 \\
\hline Central Kalimantan & 0.51 & 0.69 \\
\hline South Kalimantan & 0.54 & 0.74 \\
\hline East Kalimantan & 0.56 & 0.69 \\
\hline North Kalimantan & 0.46 & 0.62 \\
\hline North Sulawesi & 0.51 & 0.67 \\
\hline Cenrtal Sulawesi & 0.49 & 0.69 \\
\hline South Sulawesi & 0.41 & 0.67 \\
\hline Southeast Sulawesi & 0.49 & 0.64 \\
\hline Gorontalo & 0.44 & 0.67 \\
\hline West Sulawesi & 0.41 & 0.59 \\
\hline Maluku & 0.41 & 0.62 \\
\hline North Maluku & 0.41 & 0.59 \\
\hline West Papua & 0.49 & 0.72 \\
\hline Papua & 0.41 & 0.67 \\
\hline INDONESIA & 0.51 & 0.67 \\
\hline
\end{tabular}

Figure $3 a$ and Figure $3 b$ show the spatial distribution by province of the knowledge level on reproductive health among adolescents with low and high education. Adolescents with low education level tend to have a low knowledge level on reproductive health (Figure 3a). The adolescents in almost all provinces in Indonesia have a low knowledge level on reproductive health, except Bali, the only province with a high knowledge level among low-educated adolescents.

The high knowledge level on reproductive health among adolescents with low education level in Bali can be driven by 
an intensive education program on sexuality and reproductive health there. One of the ways to hold this education is through the Sekaa Teruna Taruni (STT), a traditional community-based non-formal organization that has become a culture that exists today in Bali. STT is a place for young people to develop their creativity while preserving local culture and traditions. STT, as one of the traditional non-formal organizations, is one of the targets in health promotion, especially reproductive health (Widarini et al., 2019). A research conducted by Widarini et al. (2019) reveals that the involvement of STT adolescents in the performance of drama arts that carries messages related to knowledge of premarital sex shows the effect of an increase in sexual and reproductive knowledge of adolescents in Tegallalang, Gianyar District, Bali. It confirms that education on reproductive health can be carried out effectively through traditional culture.

Meanwhile, there are several provinces that have a high knowledge level on reproductive among adolescents with a high education level. They are mainly located in Java and Bali, parts of Kalimantan (except West Kalimantan and North Kalimantan), and parts of Sulawesi (except West Sulawesi and Southeast Sulawesi). In addition, West Papua, Papua, Bangka Belitung, and Riau are also included in the category of high education level (Figure 3b).
This study confirms that there is a positive correlation between the education level and the knowledge level of adolescents. That is why many provinces have a high category of adolescents with higher education level. However, there were several provinces with low knowledge level on reproductive health among adolescents with higher education level. Formal education is one source of knowledge on reproductive health that is obtained by adolescents. Even though one of the educations on reproductive health, sexuality education, is not taught in specific subjects in Indonesia, it is implicitly integrated with subjects such as physical education, health and sports, biology, social studies and religious education (Utomo et al., 2012). A study conducted by Holzner and Oetomo (2004) on girls aged 15-24 years in Karawang, Sukabumi, and Tasikmalaya shows that 60 percent of respondents had received an education on reproductive health. However, 70 percent of them stated that the material they obtained was only related to the dangers of sex. This can support the authors' research results. Even though the adolescent population has a high education level, it does not mean that the knowledge level on reproductive health is high as well, considering that information on reproductive health obtained by the adolescents through formal education is ineffective and it only focuses on prohibiting adolescents from having sex before marriage. 


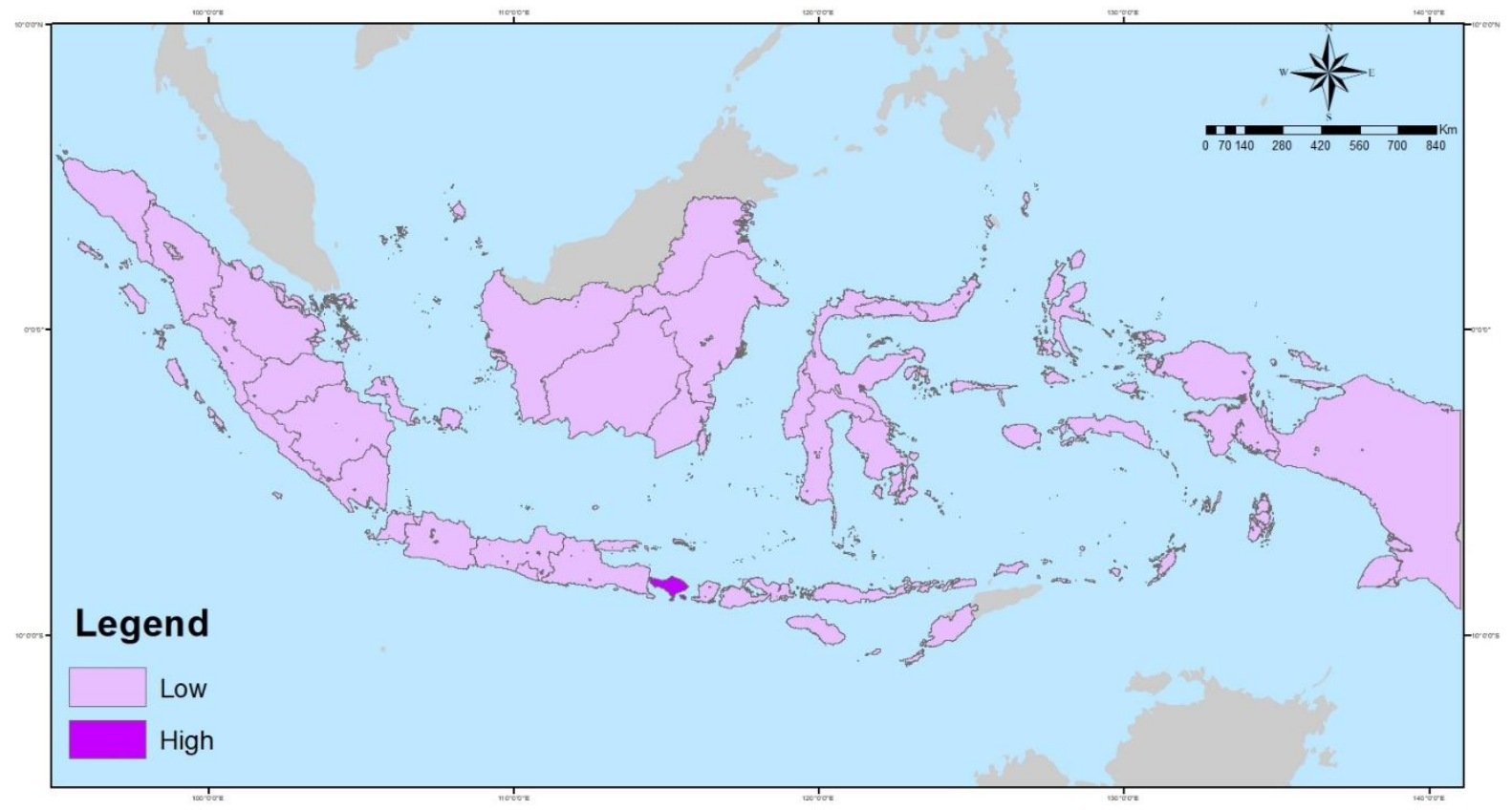

Source: 2017 IDHS Data (Processed)

Figure 3a. Spatial Distribution of the Knowledge Level on Reproductive Health among Adolescent with Low Education Level by Province, 2017

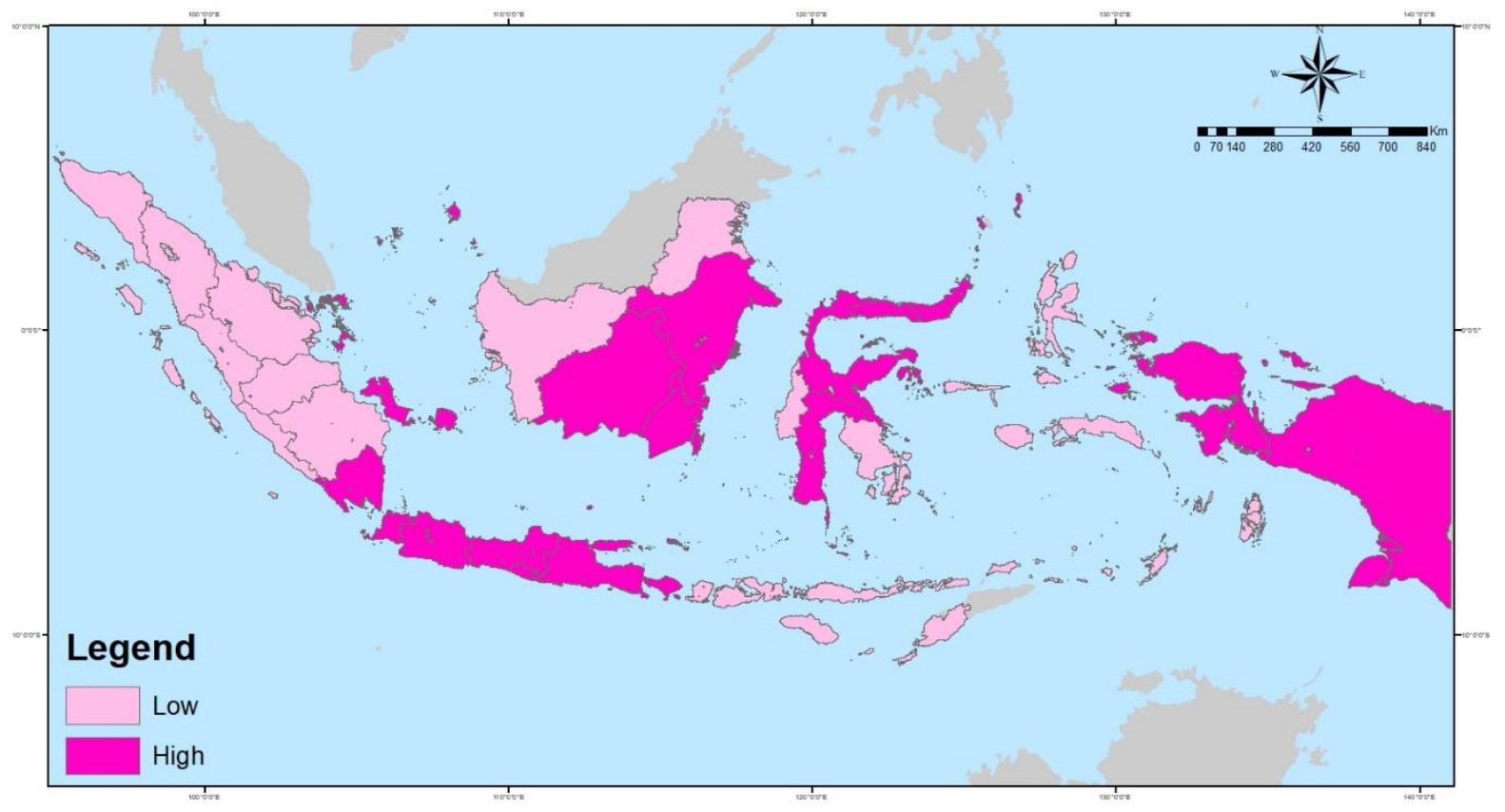

Source: 2017 IDHS Data (Processed)

Figure 3b. Spatial Distribution of the Knowledge Level on Reproductive Health among Adolescent with High Education Level by Province, 2017 
The condition of the same spatial distribution between the knowledge level among adolescents is that their knowledge level is high in the provinces located in Java and Bali and it shows the low level in the provinces other than Java, such as in the East Indonesia Archipelago. The authors assume that one of the factors that may cause these conditions is the information sources. Tarigan (2019) shows that there is a relationship between information sources and knowledge level possessed adolescents about sexually transmitted diseases. This is also in line with the results of a study conducted by Rahmawati et al. (2012) regarding the relationship between the use of various mass media and the knowledge level on reproductive health among adolescents.

A study conducted by Rahmawati et al. (2012) shows that the Spearman Rank correlation with a confidence level of $\alpha=$ 0,05 resulted in a Spearman correlation coefficient of 0.453 and a significance value of 0.000 . This figure shows that there is a quite strong and significant correlation between the use of various mass media and the knowledge level on reproductive health among adolescent. A positive correlation coefficient can also indicate that the two variables are unidirectional, where the more information adolescents get through the mass media, the higher their knowledge level on reproductive health.

Based on the 2017 IDHS data, mass media exposure to Indonesia's adolescents is indicated by the percentage of adolescents aged 15-24 years who regularly read newspapers or magazines, listen to radio, watch TV, and access the internet at least once a week in the last 12 months (Table 4). This data indicates that there is a significant difference between the provinces in Java and Bali and the provinces in the Eastern Indonesia Archipelago. Less than 10 percent of adolescents in North Maluku, West Papua, and Papua Provinces used to read newspapers or magazines at least once a week, meaning that more than 90 percent of the adolescents do not read newspapers or magazines at least once a week.

Besides, the adolescents in Maluku, North Maluku, West Papua, and Papua who used to accessing the internet were only around 40-60 percent. This is different from adolescents in the provinces located in Java and Bali in which the adolescents who are accustomed to accessing the internet were around more than 85 percent. The percentage of adolescents who are accustomed to accessing the internet at least once a week in Jakarta reached 95.6 percent. One of the reasons is the ease of internet access, especially in Java.

Based on average of mass media exposure to adolescents in the provinces located in Java and Bali and provinces in the Eastern Indonesia Archipelago, it also shows quite significant difference. The average of mass media exposure in the provinces located in Java and Bali ranged from 47.1 to 62.1 percent, while in provinces in the Eastern Indonesia Archipelago was only between 26.7 and 39.9 percent. This condition can support the results of a study conducted by Rahmawati et al. (2012) that the use of various mass media with the knowledge level on reproductive health among adolescent has a direct correlation. 
Table 4. Percentage of Unmarried Adolescents Aged 15-24 Years who Regularly Read Newspapers or Magazines, Listen to Radio, Watch TV, and Access the Internet at Least Once a Week in the Last 12 Months by Province, 2017

\begin{tabular}{ccccccc}
\hline No. & Province & $\begin{array}{c}\text { Read } \\
\text { newspapers or } \\
\text { magazines }\end{array}$ & $\begin{array}{c}\text { Listen to } \\
\text { radio }\end{array}$ & Watch TV & $\begin{array}{c}\text { Access the } \\
\text { internet }\end{array}$ & Average \\
\hline 1 & Jakarta & 18.9 & 13.1 & 83.8 & 95.6 & 52.8 \\
2 & West Java & 9.8 & 13.9 & 76.4 & 88.2 & 47.1 \\
3 & Central Java & 15.3 & 17.1 & 74.2 & 90.1 & 49.2 \\
4 & Yogyakarta & 26.3 & 22.6 & 72.2 & 93.5 & 53.6 \\
5 & East Java & 16.2 & 19.2 & 80.3 & 85.1 & 50.2 \\
6 & Banten & 20.7 & 13.4 & 77.3 & 85.1 & 49.1 \\
7 & Bali & 24.6 & 38.8 & 91.3 & 93.8 & 62.1 \\
8 & Maluku & 12.1 & 9.9 & 79.1 & 58.5 & 39.9 \\
9 & North Maluku & 6.0 & 4.9 & 67.6 & 48.5 & 31.8 \\
10 & West Papua & 3.2 & 6.3 & 80.0 & 55.4 & 36.2 \\
11 & Papua & 4.8 & 8.8 & 49.1 & 44.0 & 26.7 \\
12 & INDONESIA & 14.6 & 15.5 & 78.6 & 82.4 & 47.8 \\
\hline
\end{tabular}

Source: BPS, 2018

\section{Conclusion}

The spatial distribution of the knowledge level on reproductive health in Indonesia by province, which is distinguished by sex, shows a tendency for the knowledge level that is classified as high, especially in the provinces located in Java. Besides, there are differences in the spatial distribution of the knowledge level on reproductive health among adolescents aged 15-19 years and adolescents aged 20-24 years, where the spatial distribution of knowledge levels among adolescents aged 20-24 years classified as high tends to cover a wider area and covers many provinces. As for the spatial distribution of the knowledge level on reproductive health among adolescents with a low education level shows a tendency that is classified as low in almost all provinces in Indonesia, there are several provinces with high levels of knowledge as well while among highly educated adolescents, but there are also several provinces with low knowledge level.

In general, the same spatial distribution of the knowledge level among adolescents is it is high in the provinces located in Java and Bali, and low in the provinces outside Java, such as East Indonesia Archipelago. One of the factors causing this condition is the source of information. Most of the mass media exposure to adolescents in the provinces located inJava and Bali is higher than that of in the provinces located in Eastern Indonesia Archipelago. 


\section{References}

Asiah MD. 2009. Hubungan Tingkat Pendidikan dengan Pengetahuan Kesehatan Reproduksi Ibu Rumah Tangga di Desa Rukoh Kecamatan Syiah Kuala Banda Aceh. Jurnal Biologi Edukasi, Volume 1, No.2, 1-4.

Chen et al. 2020. Reproductive Health Status and Related Knowledge among Women Aged 20-39 Years in Rural China: A Cross-sectional Study. Reproductive Health, 17, 90.

Ernawati, Hery. 2018. Pengetahuan Reproduksi Remaja di Daerah Pedesaan. Indonesian Journal for Health Sciences Vol.02, No.01, Maret 2018, Hal 58-64.

ESCAP. 2001. Population Data Sheet. Bangkok: Population and Rural and Urban Development Division, ESCAP.

Golledge, R. G., \& Stimson, R. J. 1997. Spatial Behavior A Geographic Perspective. New York: The Guilford Press.

Handhika, Putri, Suherni, dan Sumarah. 2017. Hubungan Tingkat Pengetahuan Kesehatan Reproduksi Remaja dengan Sikap Seksual Pranikah di SMK Taman Siswa Nanggulan Tahun 2017. Jurnal Kesehatan Ibu dan Anak, Volume 11, No.2, November 2017, hal. 31-34.

Hastuti dan A.J.Suhardjo. 2006. Keterkaitan Lingkungan Geografi, Kondisi SosialEkonomi dan Pembagian Kerja Secara Seksual di Perdesaan. Majalah Geografi Indonesia, Volume 20, Nomor 2.

Holzner B.M., dan Oetomo D. Youth. Sexuality and Sex Education Messages in Indonesia: Issues of Desire and Control. Reproductive Health Matters 2004, 12 (23), 40-49.

Irawan, E. 2016. Gambaran Pengetahuan Remaja Tentang Kesehatan Reproduksi di Desa Kertajaya. Jurnal IImu Keperawatan, Vol. IV, No.1.

Iswarati. 2011. Pengetahuan dan Sumber Informasi Kesehatan Reproduksi
Remaja di Indonesia. Jurnal Manajerial Vol. 9, No. 18, Januari 2011, 1 - 16.

Kementerian Kesehatan RI. 2019. Indeks Pembangunan Kesehatan Masyarakat 2018. Jakarta: Lembaga Penerbit Badan Penelitian dan Pengembangan Kesehatan (LPB).

Martini. 2015. Faktor - Faktor yang Berhubungan dengan Kejadian Anemia pada Remaja Putri di SMAN 1 Metro. Jurnal Kesehatan Metro Sai Wawai, Vol 8, No. 1.

Oktarina, Fachrudi Hanafi, dan Made Asri Budisuari. 2009. Hubungan antara Karakteristik Responden, Keadaan Wilayah dengan Pengetahuan, Sikap terhadap HIVIAIDS pada Masyarakat Indonesia. Buletin Penelitian Sistem Kesehatan - Vol. 12 No. 4.

Pakasi, Diana T. dan Reni Kartikawati. 2013. Antara Kebutuhan dan Tabu: Pendidikan Seksualitas dan Kesehatan Reproduksi bagi Remaja di SMA. Jurnal Makara Seri Kesehatan, Vol. 17, No. 2.

Panonsih, Resati Nando, dkk. 2020. Hubungan Pendidikan dengan Pengetahuan Tentang Infeksi Menular Seksual pada Gay, Transgender, dan LSL. ARTERI: Jurnal IImu Kesehatan p-ISSN 2721-4516 Vol. 1, No. 3, Mei 2020, hlm. 205-211.

Pratiwi, N. L. dan Basuki, H. 2011. Hubungan Karakteristik Remaja Terkait Risiko Penularan HIV-AIDS dan Perilaku Seks Tidak Aman di Indonesia. Buletin Penelitian Sistem Kesehatan, Vol. 14, No. 4, Oktober 2011, 346-357.

Purwanto, E, Soejoenoes, A., dan Binarso, A. 2010. Perbandingan Tingkat Pengetahuan Kesehatan Reproduksi Siswi Sekolah Menengah Umum Di Pedesaan dan Perkotaan. Tesis. Semarang: Universitas Diponegoro.

Rahmawati, Vivin E, Ninik Azizah, dan Suyati. 2012. Hubungan Pemanfaatan Beberapa Jenis Media Massa dengan Tingkat 
Pengetahuan Kesehatan Reproduksi pada Remaja Kelas XI SMA. Prosiding Seminas Competitive Advantage, Vol. 1, No.2.

Sari, Puspa, et al. 2019. Pengetahuan Remaja Putri Mengenai Anemia Defisiensi Besi dan Pencegahannya di Kecamatan Jatinangor. Jurnal Aplikasi Ipteks untuk Masyarakat Vol. 8, No. 4, Desember 2019, $265-267$.

Sutono dan Umi Listyaningsih. 2014. Pengetahuan Kesehatan Reproduksi dan Perilaku Berpacaran Remaja Menurut Wilayah di DI Yogyakarta. Jurnal Bumi Indonesia Vol. 3, No. 1.

Suwaryo, Putra A.W. dan Podo Yuwono. 2017. Faktor-Faktor yang Mempengaruhi Tingkat Pengetahuan Masyarakat dalam Mitigasi Bencana Alam Tanah Longsor. The 6th University Research Colloquium 2017 Universitas Muhammadiyah Magelang.

Tarigan, Eka Ristin. 2019. Hubungan Sumber Informasi dengan Pengetahuan Remaja tentang Penyakit Menular Seksual di SMA Swasta Masehi GBKP Berastagi. Indonesian Trust Health Journal Volume 1, No.2, April 2019.
Utomo, I, McDonald P, dan Hull T. 2012. Improving Reproductive Health Education in the Indonesian National Curriculum. Gender and Reproductive Health Study Policy BriefNo. 2. Canberra: Australian National University.

Wahyuni, Siti, 2012. Hubungan antara Pengetahuan Remaja tentang Penyakit Menular Seksual (PMS) dengan Jenis Kelamin dan Sumber Informasi di SMAN 3 Banda Aceh Tahun 2012. Jurnal IImiah STIKES U'Budiyah Vol.1, No.2, Maret 2012.

Wawan, A dan Dewi M. 2011. Teori dan Pengukuran Pengetahuan, Sikap, dan Perilaku Manusia. Cetakan II. Yogyakarta: Nuha Medika.

Widarini, Ni Putu, et al. 2019. Reproductive Health Promotion Through Traditional Art Media Reduced Premarital Sex Intention among Adolescent Population in Gianyar, Bali. Bali Medical Journal (Bali Med J) 2019, Vol. 8, No. 3, 706-711.

Zhang, Dongxian, et al. 2010. Sexual and Reproductive Health Knowledge among Female College Students in Wuhan, China. Asia-Pacific Journal of Public Health Volume 22, Number 1, January 2010, 118-126. 